\title{
MODELIRANJE DEBLJINE KORE BUKVE (Fagus sylvatica L.)
}

\section{MODELING BARK THICKNESS OF BEECH (Fagus sylvatica L.)}

\author{
Ahmet LOJO' ${ }^{\text {, Jusuf MUSIĆ }}{ }^{1}$, Besim BALIĆ ${ }^{1}$, Admir AVDAGIĆ ${ }^{1}$, Velid HALILOVIĆ ${ }^{1}$, Aida IBRAHIMSPAHIĆ1, \\ Jelena KNEŽEVIĆ'
}

\begin{abstract}
SAŽETAK
Debljina kore i njen udio u obujmu oblog drva predstavljaju bitne značajke u tehnološkom procesu pridobivanja drva, posebno u fazi preuzimanja drva. S obzirom da je itekako važno raspolagati s relativno točnim podacima ovih značajki kore za pojedine vrste drveća, osnovni cilj ovoga rada je istražiti navedene značajke kore bukve. Istraživanje je provedeno na području Kantona 10, a obuhvatilo je 678 stabla bukve od 10 do $85 \mathrm{~cm}$ promjera na prsnoj visini i od 5 do $40 \mathrm{~m}$ visine. Mjerenje srednjeg promjera i debljine kore obavljeno je metodom sekcioniranja, a ukupno je izmjereno 6.403 promjera i debljina kore ili 9,4 mjerenja po jednom stablu u prosjeku. Rezultati su pokazali sljedeće: a) povećanjem srednjeg promjera oblog drva dvostruka debljina kore povećava se od 6,05 $\mathrm{mm}$ (debljinski razred $12,5 \mathrm{~cm}$ ) do $20,69 \mathrm{~mm}$ (debljinski razred $82,5 \mathrm{~cm}$ ); b) povećanjem srednjeg promjera oblog drva udio se kore $\mathrm{u}$ obujmu eksponencijalno smanjuje od 9,44\% (debljinski razred 12,5 $\mathrm{cm}$ ) do 4,95\% (debljinski razred 82,5 $\mathrm{cm}$ ). Utvrđene razlike u komparaciji s drugim autorima koji su istraživali ove značajke kore bukve, ukazuju na važnost nastavka istraživanja i na drugim područjima u $\mathrm{BiH}$. Na taj način bi se dobili pouzdaniji rezultati koji bi bili primjenjivi za cijelu državu ili parcijalno za pojedine njene dijelove, ako se razlika između područja pokaže statistički značajnom. Dobiveni rezultati predstavljaju nezaobilaznu polaznu osnovu za izradu tablica kore bukve i novog pravilnika o načinu izmjere oblog drva i utvrđivanja količina.
\end{abstract}

KLJUČNE RIJEČI: bukva, debljina kore, udio kore, oblo drvo

\section{UVOD}

\section{INTRODUCTION}

Europska bukva (Fagus sylvatica L) jedna je od najvažnijih i najrasprostranjenijih vrsta listača u Europi, s prirodnim arealom između 17 i 20 milijuna hektara (Paule 1995). Uporaba bukovog drva je izuzetno velika. Koristi se za proizvodnju različitog namještaja, izradu ljuštenih furnira, željezničkih pragova, raznih vrsta drvnih ploča, parketa, paleta, drvne galanterije, prešanih laminata, preradu celuloze, proizvodnju drvenog uglja itd. S oko 250 poznatih načina uporabe drva, bukva je najraznolikija vrsta listača u Europi glede toga. Kora debla je tanka i glatka, karakteristične srebrno-sive boje. Ova značajka omogućava pisanje po njoj, pri čemu tragovi ostaju vidljivi dugi niz godina i zasigurno je da su se brojni narodi u Evropi nekada sporazumijevali pisanjem po kori bukve (Trinajstić 2003).

$\mathrm{Na}$ temelju podataka provedene Druge nacionalne inventure šuma u $\mathrm{BiH}$, ukupna površina dostupnih šuma gdje je zastupljena bukva iznosi 984.700 ha, sa oko $183.925 .200 \mathrm{~m}^{3}$ zalihe. To iznosi $41 \%$ od ukupne površine i 40,4\% od ukupne zalihe svih dostupnih šuma u BiH, što je čini gospodarski najvažnijom vrstom. Rasprostranjenost šuma u kojima je zastupljena bukva u BiH prikazana je na slici 1 .

\footnotetext{
Prof. dr. Ahmet Lojo, E-mail: a.lojo@sfsa.unsa.ba; Prof. dr. Jusuf Musić, E-mail: j.music@sfsa.unsa.ba; Prof .dr. Besim Balić, E-mail: b.balic@sfsa.unsa.ba; Doc. dr. Admir Avdagić, E-mail: a.avdagić@sfsa.unsa.ba; Prof. dr. Velid Halilović, e-mail: v.halilovic@sfsa.unsa.ba; Prof. dr. Aida lbrahimspahić, E-mail: a.ibrahimspahic@sfsa.unsa.ba; MA Jelena Knežević, e-mail: j.knezevic@sfsa.unsa.ba, Šumarski fakultet Univerziteta u Sarajevu, Zagrebačka 20, 71000 Sarajevo, BiH.
} 


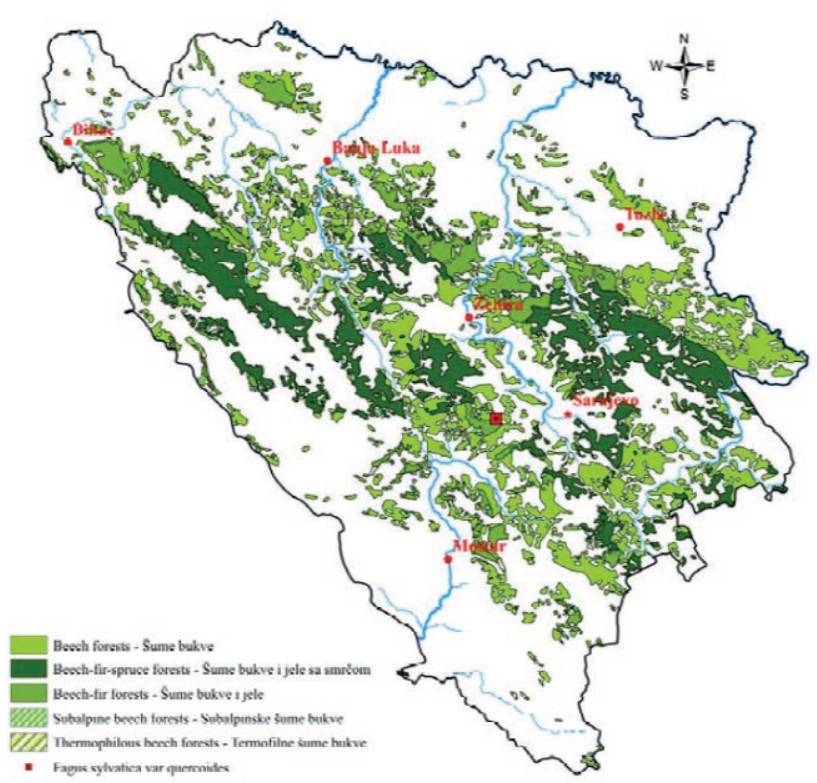

Slika 1. Karta realne šumske vegetacije neutrofilnih i acidofilnih šuma bukve u BiH (Selimović i Vojniković, prema Stefanović i dr. 1983)

Figure 1. The map of real forest vegetation of neutrophilic and acidophilic beech forest in BGH (Selimović and Vojniković, according Stefanović et al. 1983)

Važnost kore kao vanjskog omotača stabla ogleda se u nekoliko bitnih čimbenika: (1) pruža zaštitu za njegov rast, (2) može se koristiti kao izvor energije ili proizvodnju specijalnih proizvoda (malč, tanini, bojila, farmaceutski proizvodi i dr.) i (3) utječe na ostvarene prihode jer se tehnička oblovina standardizirano mjeri i prodaje na temelju obujma bez kore. Stoga su znanja o debljini kore i mogućnost što točnije procjene njenog udjela u stablu i drvnim sortimentima izuzetno važna u današnjoj trgovini drvom. Netočne procjene mogu za vlasnika šume rezultirati gubitkom vrijednosti i do $11 \%$ (Marshal i dr. 2006). Istraživanja debljine i postotnog udjela kore u obujmu stabala ili oblog drva, između ostalog, potaknuta su i pomakom u pogledu komercijalne važnosti kore od neželjenog ostatka na vrijedno gorivo i izvor biomaterijala visoke vrijednosti (Doruska i dr. 2009) te kora postaje sve važnija za proizvodnju energije iz biomase (Adler 2007).

Značajke kore najizraženije su upravo u tehnološkom procesu pridobivanja drva. Naime, njena debljina i tvrdoća nisu bez značaja u fazi sječe i izrade, a njezin izgled, odnosno vanjska površina, odlučujuća je za veličinu koeficijenta trenja kod privlačenja drva. Također, specifična masa kore veća je od specifične mase drva što djeluje kao negativan faktor kod privlačenja, utovara, prijevoza i istovara tehničke oblovine (Krpan 1986). Ipak, od svih značajki kore, s praktičnog gledišta, svakako je najznačajnija njena debljina.

Prva istraživanja o debljini i obujmu kore proveo je Flurry u Švicarskoj krajem devetnaestog stoljeća. Cilj im je bio utvrđivanje faktora za konverziju obujma s korom u obujam bez kore, a predstavljala su početak još uvijek aktualnih istraživanja kore različitih vrsta drveća u mnogim dijelovima svijeta (Stängle i dr. 2017). Ranija istraživanja uglavnom su bila fokusirana na procjenu njene debljine na prsnoj visini (Klepac 1957, Klepac 1958, Monserud 1979 i drugi), s obzirom da se ukupan obujam kore stabla može približno izračunati ukoliko se raspolaže s informacijom o njenoj debljini na prsnoj visini. Ipak, u novije vrijeme istraživači se sve više bave i utjecajem drugih čimbenika na debljinu kore kao što su relativna visina stabla, kvaliteta staništa, nadmorska visina, starost i dr. (Wilhelmssoni dr. 2002, Prka 2004, Laasasenaho i dr. 2005, Božić i dr. 2007, Atici 2009, Stankić i dr. 2010, Cellini i dr. 2012, Lojo i dr. 2019, Musić i dr. 2019 i drugi).

Na prostoru bivše Jugoslavije najprije se počelo sa istraživanjem debljine kore listača (Milojković 1953, Klepac 1957, 1958, Bojanin 1972). Naime, propisi o načinu izmjere i utvrđivanja količina te propisi o načinu isporuke oblog drva listača uvjetovali su razumljiv i opravdan interes za što točnijim utvrđivanjem njihove debljine kore i postotnog udjela u obujmu stabala ili oblog drva. Dvostruku debljinu kore bukve na prsnoj visini Klepac (1958) izravnava linearnom funkcijom, pri čemu zaključuje da na debljinu kore u velikoj mjeri utječu i ekološke prilike te način gospodarenja. Zaključuje da su Meyer-Wegelinovi podaci o debljini bukove kore u Zapadnoj Njemačkoj niži od podataka koje je on dobio i to posebice za tanja stabla, što opravdava važnost provedenih istraživanja. Za bukvu u zapadnoj Hrvatskoj utvrđuje prosječan postotni udio kore u ukupnoj drvnoj masi od 6,8\%. Krpan (1986) je u okviru svojih istraživanja debljinu kore bukve u ovisnosti o srednjem promjeru oblog drva izjednačio parabolom drugog reda. Također, navodi da prosječni postotni udio kore iznosi 6,3\% u starijim sastojinama i 5,9\% u mlađim sastojinama. Prka (2004) kod bukve u sječinama Bjelovarske Bilogore istražuje postotni udio kore u obujmu tehničke oblovine u ovisnosti o vrsti sjeka te zaključuje da nema značajnih razlika između dvostruke debljine kore ovisno o promjeru u pripremnim, naplodnim i dovršnim sječama. Ovisnost dvostruke debljine kore o promjeru za cijeli uzorak izravnava linearnom funkcijom. Sve utvrđene debljine kore (apsolutne i relativne) manje su od rezultata koje je dobio Krpan (1986), što objašnjava razlikama u nadmorskoj visini objekata istraživanja i boljim ekološkim prilikama na istraživanom području.

Tezu da lošija životna sredina iskazana tzv. „Site Indeksom“ uvjetuje veću debljinu kore potvrđuju i istraživanja koja je u Turskoj za orijentalnu bukvu (Fagus orientalis Lipsky) proveo Atici (2009). U okviru ovih istraživanja utvrđuje prosječan postotni udio kore od $4,75 \%$. Utjecaj ekoloških prilika na debljinu kore orijentalne bukve utvrdili su i Bonyad i dr. (2012). Rezultati njihovih istraživanja pokazali su da je debljina kore bukve bila značajno različita u ovisnosti o geografskim čimbenicima (studijskim područjima), odnosno 
Tablica 1. Distribucija ukupnog broja modelnih stabala prema debljinskim i visinskim stupnjevima Table 1. Distribution of the total number of model trees according to diameter and height degrees

\begin{tabular}{|c|c|c|c|c|c|c|c|c|c|}
\hline \multirow{2}{*}{$\begin{array}{c}\text { Promjer (cm) } \\
\text { Diameter }(\mathrm{cm})\end{array}$} & \multicolumn{7}{|c|}{ Visina (m) - Height (m) } & \multicolumn{2}{|c|}{$\mathrm{n}_{\mathrm{i}}$} \\
\hline & 7,5 & 12,5 & 17,5 & 22,5 & 27,5 & 32,5 & 37,5 & Broj - No & $\%$ \\
\hline 12,5 & 2 & 26 & 11 & 1 & & & & 40 & 5,90 \\
\hline 17,5 & 2 & 28 & 49 & 13 & & & & 92 & 13,57 \\
\hline 22,5 & & 20 & 54 & 17 & & & & 91 & 13,42 \\
\hline 27,5 & & 9 & 52 & 28 & 6 & & & 95 & 14,01 \\
\hline 32,5 & & 1 & 23 & 35 & 8 & & & 67 & 9,88 \\
\hline 37,5 & & 1 & 19 & 40 & 5 & & & 65 & 9,59 \\
\hline 42,5 & & & 3 & 41 & 9 & & & 53 & 7,82 \\
\hline 47,5 & & & 2 & 13 & 33 & 2 & 1 & 51 & 7,52 \\
\hline 52,5 & & & 1 & 13 & 30 & 7 & & 51 & 7,52 \\
\hline 57,5 & & & & 5 & 19 & 6 & & 30 & 4,42 \\
\hline 62,5 & & & & 1 & 17 & 8 & & 26 & 3,83 \\
\hline 67,5 & & & & & 7 & 2 & & 9 & 1,33 \\
\hline 72,5 & & & & & 2 & 4 & 1 & 7 & 1,03 \\
\hline 82,5 & & & & & & & 1 & 1 & 0,15 \\
\hline Suma - Sum & 4 & 85 & 214 & 207 & 136 & 29 & 3 & 678 & 1000 \\
\hline$\%$ & 0,59 & 12,54 & 31,56 & 30,53 & 20,06 & 4,28 & 0,44 & 100,0 & \\
\hline
\end{tabular}

maksimalna na sjeveru, a minimalna na jugu, što pripisuju ekološkim varijacijama u tim područjima.

U Bosni i Hercegovini debljinu kore bukve istraživao je Bektić (2015). Ovisnost dvostruke debljine kore o srednjem promjeru oblog drva iskazuje linearnom funkcijom. Za cijeli uzorak prosječni udio kore iznosi 5,20\%. Sortimentne tablice za najvažnije vrste drveća koje se koriste u $\mathrm{BiH}$, uz čitav niza drvnih sortimenata sadrže i kategoriju „otpadak”. S praktičnog gledišta ova kategorija može se podijeliti na "pravi otpadak“ i gubitke. Pravi otpadak u tom smislu čine različiti neizrađeni dijelovi krupnog drva i piljevina, dok gubitke uzrokuju propisani način izmjere dimenzija i utvrđivanja količina te odbijena dvostruka debljina kore. Analizirajući različite izvore gubitaka obujma izrađene oblovine smreke zbog propisanog načina izmjere u Hrvatskoj, Poršinsky i Vujeva (2007) su kao izvor najvećeg gubitka identificirali odbitak dvostruke debljine kore. Shodno navedenom za poduzeća šumarstva je izuzetno važno da ti gubici budu što manji, odnosno da se raspolaže što točnijim podacima o debljini kore pojedinih vrsta drveća. Otuda i osnovni motiv za ovo istraživanje.

\section{MATERIJAL I METODE MATERIAL AND METHODS}

Unatoč značaju određenih parametara, kao što su način izmjere debljine kore, veličina uzorka i njegov raspored na istraživanom području, u literaturi im nije posvećena adekvatna pozornost (Stängle i dr. 2016). Husch i dr. (2003) kao generalno pravilo navode da je za utvrđivanje faktora kore na prsnoj visini neophodan uzorak od 20 do 50 stabala. Studije koje istražuju modele koničnosti, koji mogu uključivati izmjeru promjera sa ili bez bez kore, iznimno su varijabilne. Ono što je od kritične važnosti je da uzorak treba obuhvatiti variranje debljine kore na području istraživanja uz najniže moguće troškove (Stängle i dr. 2016).

Uzorak ovog istraživanja činilo je ukupno 678 stabala bukve izabranih na širem području unutar državnih raznodobnih sastojina u Kantonu 10. Radi objektivnog istraživanja utjecaja različitih faktora od kojih ovisi debljina kore u uzorak su odabrana samo normalno formirana stabla, odnosno stabla bez vidljivih nepravilnosti na deblu. Prilikom izbora modelnih stabala vodilo se računa da u uzorku budu zastupljena stabla svih debljinskih i visinskih stupnjeva (tablica1). Osim toga težilo se da u uzorku budu zastupljena stabla bukve sa raznih lokaliteta (općina) shodno njihovom učešću u zalihi bukovih stabala cijeloga područja (tablica 2). Odabrana stabla su mjerena u oborenom stanju metodom sekcioniranja sa sekcijama nejednakih apsolutnih dužina $(1-2 \mathrm{~m})$.

Iz tablice 1 je razvidno da su izabrana stabla bukve u rasponu od $10,0 \mathrm{~cm}$ do $85,0 \mathrm{~cm}$ prsnog promjera te od 5 do 40 metara

Tablica 2: Distribucije broja modelnih stabala po općinama Table 2. Distributions of the number of model trees by municipality

\begin{tabular}{|cc|}
\hline Naziv općine & $\begin{array}{c}\text { Broj modelnih stabala } \\
\text { Nume of the municipality }\end{array}$ \\
\hline Kupres & 77 \\
Livno & 126 \\
Glamoč & 142 \\
Grahovo & 139 \\
Drvar & 159 \\
Tomislavgrad & 35 \\
UKUPNO & 678 \\
\hline
\end{tabular}


visine. Broj stabala u uzorku se smanjuje sa povećanjem debljine što više-manje odgovara debljinskoj strukturi osnovnog skupa. Distribucija broja stabala po visinskim stupnjevima je drukčija i po obliku je slična normalnoj distribuciji. Najzastupljenija su stabla u rasponu od 15 do $25 \mathrm{~m}$ visine, dok se prema višim i nižim visinskim stupnjevima njihov broj smanjuje.

Na svakom deblu mjereno je više promjera, počevši od panja, a udaljenost mjesta mjerenja promjera od panja iskazana je u relativnim jedinicama od duljine oborenog debla. Premjerom je obuhvaćena samo drvna masa iznad $7 \mathrm{~cm}$ promjera na tanjem kraju bez kore (krupno drvo). Na svakom mjestu na deblu (sekciji) mjereni su:

- srednji promjer s korom (na sredini sekcije) u centimetrima s točnošću na milimetar, unakrsno,

- debljina kore na milimetar točnosti, na mjestima dodira promjerke s deblom.

Prilikom izmjere debljine kore pravljen je tzv. „Zates“ (okomit na deblo) do drva da bi se debljina kore mogla jasno vidjeti i precizno izmjeriti (slika 2), a sama izmjera obavljena je pomičnim mjerilom (šublerom). Naime, izmjerom tzv. Švedskim mjeračem kore generalno se precjenjuje njena debljina, jer se pri izmjeri dijelom zadire u drvo, a osjetljiva je i na sezonu uzorkovanja (Althen 1964). Uz to, jako je ovisna o subjektivnom osjećaju snimača (Mesavage 1969) te je potrebna velika vještina pri takvom načinu utvrđivanja debljine kore kako bi se prepoznao trenutak kada sječivo dosegne drvo (Stankić i dr. 2010). Iz navedenih razloga, a koji su potvrđeni i našim probnim radom s ovim instrumentom, odlučeno je da se izmjera obavi na opisani način.

$\mathrm{Na}$ uzorku istraživanja od 678 stabala bukve izmjereno je ukupno 6.403 promjera i debljina kore, što je u prosjeku 9,4 izmjera po jednom stablu.

Istraživanje zavisnosti debljine kore od utjecajnih faktora izvršeno je GLM analizom (Generalized linear models) koja

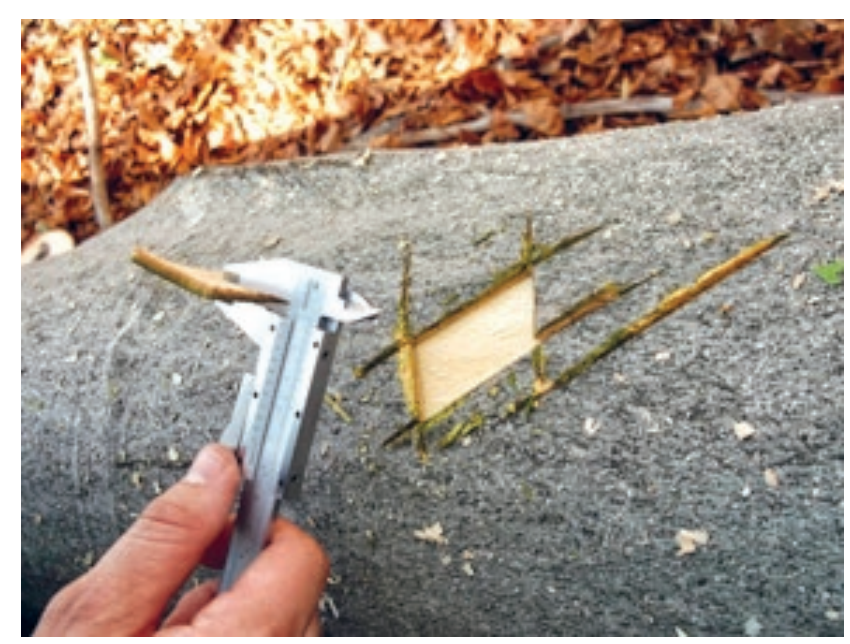

Slika 2. Zates na deblu

Figure 2. Notch on stem istovremeno kombinira metodu analize varijance i regresije. Rezultat GLM analize je kompleksna regresijska jednadžba koja sadrži i parametre uz pojedine kategorijske varijable odnosno slučajeve unutar kategorijskih varijabli. Pri obradi podataka i interpretaciji rezultata korišten je statistički program STATGRAPHICS Centurion XVII. Za obračun postotnog udjela kore u obujmu sekcije (dijela debla) korišten je Meyerov obrazac (Meyer 1946). On je pretpostavio da je oblični broj stabla s korom jednak obličnom broju stabla bez kore i temeljem te pretpostavke izveo sljedeću jednadžbu za obračun postotnog udjela kore:

$$
p_{k}=\left(1-\frac{d^{2}}{D^{2}}\right) \cdot 100[\%]
$$

gdje je:

$\mathrm{p}_{\mathrm{k}}$ - udio kore u obujmu dijela debla,

$\mathrm{d}$ - promjer bez kore i

D - promjer sa korom.

\section{REZULTATI I RASPRAVA RESULTS AND DISCUSSION}

\section{Debljina kore bukve - Bark thickness of beech}

U skladu s rezultatima ranije provedenih istraživanja o faktorima koji utječu na debljinu kore pretpostavljeno je ona, između ostalog, ovisi i o mjestu mjerenja na deblu, odnosno udaljenosti od panja prema njegovom vrhu. U cilju utvrđivanja ovog utjecaja svako deblo podijeljeno je u 5 sekcija jednakih relativnih duljina $\left(\mathrm{DIO}_{\text {debla }}\right)$. Prva sekcija (1) obuhvaća donju petinu ukupne duljine debla (od panja), druga sekcija (2) obuhvaća iduću petinu itd. Ova hipoteza je provjerena statističkom analizom podataka korištenjem GLM analize. Pri tome je zavisna varijabla bila dvostruka debljina kore ( $D_{\text {kore }} \mathrm{u}$ milimetrima), a kao nezavisne varijable su uzete:

- srednji promjer sekcije (dijela debla) - Ds sekcije (cm) kao kontinuirana varijabla i

- relativna udaljenost promjera sekcije od panja - DI$\mathrm{O}_{\text {debla }}$ kao kategorijska varijabla.

U statističkoj analizi najprije je provjerena normalnost nezavisne varijable (Ds sekcije) i potreba za potencijalnim transformacijama (Box i Cox 1964). Utvrđeno je da distribucija originalnih podataka odstupa od normalne, a za njihovu optimalnu transformaciju utvrđen eksponent $\lambda=$ 0,158 . Ista procedura provedena je i za zavisnu varijablu. Utvrđeno je da za postizanje približno normalne distribucije veličina dvostruke debljine kore $\left(D_{\text {kore }}\right)$ također treba primijeniti potencijalnu transformaciju s eksponentom $\lambda$ $=0,175$. Nakon provedenih transformacija utvrđen je sljedeći regresijski model s koeficijentom višestruke determinacije $\mathrm{R}^{2}=0,741$ : 
$\operatorname{Box} \operatorname{Cox}\left(D_{\text {kore }}\right)=-22,8365-0.933113 \cdot \mathrm{I} 1(1)-$ $0,726607 \cdot \mathrm{I} 1(2)-0,273016 \cdot \mathrm{I} 1(3)+0,498806 \cdot \mathrm{I} 1(4)+$

gdje je:

$24,2884 \cdot \mathrm{Ds}_{\text {sekcije }}^{0,158}$

$$
\operatorname{Box} \operatorname{Cox}\left(\mathrm{D}_{\text {kore }}\right)=\frac{\mathrm{D}_{\text {kore }^{0,175}}-1}{0,175 \cdot 8,71857^{-0,825}}
$$

I1(1) = 1 ako je $\mathrm{DIO}_{\text {debla }}=1,-1$ ako je

$\mathrm{DIO}_{\text {debla }}=5,0 \mathrm{u}$ drugom slučaju

$\mathrm{I} 1(2)=1$ ako je $\mathrm{DIO}_{\text {debla }}=2,-1$ ako je

$\mathrm{DIO}_{\text {debla }}=5,0 \mathrm{u}$ drugom slučaju

$\mathrm{I1}(3)=1$ ako je $\mathrm{DIO}_{\text {debla }}=3,-1$ ako je

$\mathrm{DIO}_{\text {debla }}=5,0 \mathrm{u}$ drugom slučaju

$\mathrm{I1}(4)=1$ ako je $\mathrm{DIO}_{\text {debla }}=4,-1$ ako je

$\mathrm{DIO}_{\text {debla }}=5,0 \mathrm{u}$ drugom slučaju

U tablici 3 prikazana je analiza varijance modela rezidualnog odstupanja i ukupna varijanca debljine kore. Na osnovi vrijednosti odnosa varijanci (F-odnos) i vjerojatnoće greške („p“-vrijednost), možemo zaljučiti da analizirani faktori imaju statistički značajan utjecaj na veličinu dvostruke debljine kore.

U daljnjem postupku analize utjecaja nezavisnih na zavisnu varijablu, a na osnovi rezultata analize komponenti (izvora variranja) i F-odnosa varijanci prikazanih u tablici 4 može se zaključiti da najveći utjecaj na debljinu kore ima izmjereni promjer dijela debla transformiran eksponentom 0,158, a što je i očekivano. Također, može se zaključiti i da varijabla $\mathrm{DIO}_{\text {debla }}$ ima statistički značajan utjecaj na debljinu kore.

Na slici 3 prikazane su prosječne debljine kore za dijelove debla istih promjera ali različite relativne udaljenosti od panja prema vrhu debla i najmanje značajne razlike pri vjerojatnoći od 95\%. Vidljivo je da se debljina kore povećava

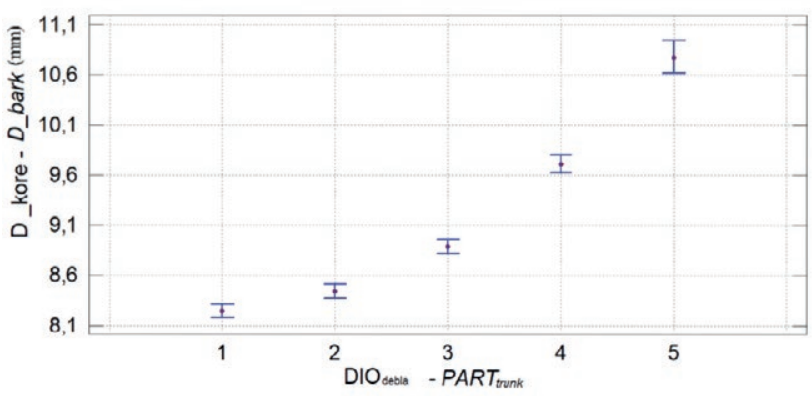

Slika 3. Prosječne debljine kore i Fisherov LSD interval pojedinih sekcija istog promjera na mjestu mjerenja

Figure 3. Average bark thickness and Fisher LSD intervals of particular sections of the same diameter at the point of measuring

od dna debla prema njegovom vrhu. To znači da komadi drva istog promjera imaju deblju koru ako se nalaze bliže vrhu stabla.

Prema dostupnoj literaturi ovaj utjecaj istraživao je Bojanin (1972) kod jasena, ali nije utvrdio signifikantnu razliku. Utvrđeni utjecaj varijable $\mathrm{DIO}_{\text {debla }}$ na debljinu kore u principu je logičan i uvjetovan je, ponajprije, zakonitostima debljinskog prirasta. Naime, debljinski prirast duž debla stabala najmanji je na određenoj visini, ispod ili iznad prsne visine. Visina najmanjeg debljinskog prirasta ovisi o starosti, debljini stabla i uvjetima staništa. Prema vrhu i prema podnožju stabla od tog mjesta (visine) debljinski prirast se povećava i najveći je na vrhu stabla (Guttenberg, prema Matić 1980). Činjenica da povećanje debljinskog prirasta prati i povećanje debljine kore govori u prilog dobivenim rezultatima.

\section{Matematički model primjenljiv u šumarskoj praksi -} Mathematical model applicable in forestry practice

Prethodno utvrđeni matematički model, nažalost, ima samo znanstveni značaj bez aplikativnog karaktera. Naime,

Tablica 3. Analiza varijance za debljinu kore bukve regresijskog modela

Table 3. The analysis of variance for the thickness of the beech bark of the regression model

$\begin{array}{lccccc}\text { Izvor variranja } & \begin{array}{c}\text { Varijanca } \\ \text { Sum of squares }\end{array} & \begin{array}{c}\text { Stupanj slobode } \\ \text { Deg. of freedom }\end{array} & \begin{array}{c}\text { Sredina kvadrata } \\ \text { Mean Square }\end{array} & \begin{array}{c}\text { F-odnos } \\ \text { F-ratio }\end{array} & \text { "p" vrijednost } \\ \text { "p" value } & \\ \text { Model - Model } & 64957,7 & 5 & 12991,5 & 3656,06 & <0,0001 \\ \text { Rezidual - Residual } & 22731,3 & 6397 & 3,55343 & & \\ \text { Ukupno - Total (Corr.) } & 87689,0 & 6402 & & & \end{array}$

Tablica 4. GLM analiza utjecaja nezavisnih na zavisnu varijablu u regresijskom modelu

Table 4. GLM analysis of the influence of independent variables on the dependent variable in the regression model

\begin{tabular}{|c|c|c|c|c|c|}
\hline $\begin{array}{l}\text { Izvor variranja } \\
\text { Source of variability }\end{array}$ & $\begin{array}{c}\text { Varijanca } \\
\text { Sum of squares }\end{array}$ & $\begin{array}{l}\text { Stupanj slobode } \\
\text { Deg. of freedom }\end{array}$ & $\begin{array}{l}\text { Sredina kvadrata } \\
\text { Mean Square }\end{array}$ & $\begin{array}{c}\text { F-odnos } \\
F-\text { ratio }\end{array}$ & $\begin{array}{c}p \text {-vrijednost } \\
p \text {-value }\end{array}$ \\
\hline $\mathrm{DIO} 0_{\text {debla }}-P A R T_{\text {trunk }}$ & 1809,84 & 4 & 452,459 & 127,33 & $<0,0001$ \\
\hline Ds sekcije ${ }^{0,158}-D m$ section $^{0,158}$ & 48300,5 & 1 & 48300,5 & 13592,64 & $<0,0001$ \\
\hline Rezidual - Residual & 22731,3 & 6397 & 3,55343 & & \\
\hline Ukupno - Total (Corr.) & 87689,0 & 6402 & & & \\
\hline
\end{tabular}


Tablica 5. Parametri funkcije procjene dvostruke debljine kore bukve i njihovi statistički pokazatelji Table 5. Parameters of the double bark thickness estimation function and their statistical indicators

$\begin{array}{lcccc}\text { Parametar } & \text { Veličina } & \text { Standardna greška } & \mathrm{t} \text {-statistički } & \mathrm{p}-\text { vrijednost } \\ \text { Parameter } & \text { Estimate } & \text { Standard Error } & t-\text { statistic } & p-\text { value } \\ \text { SI. član (a) - Intercept } & 0,638098 & 0,0119696 & 53,3101 & <0,0001 \\ \text { b -uz nezavisnu varijablu - Slope } & 0,557834 & 0,00432687 & 128,923 & <0,0001\end{array}$

Tablica 6. Analiza variance

Table 6. Variance analysis

$\begin{array}{lccccc}\text { Izvor variranja } & \text { Varijanca } & \text { Stupanj slobode } & \text { Sredina kvadrata } & \text { F-odnos } & p \text {-vrijednost } \\ \text { Source of variability } & \text { Sum of quares } & \text { Deg. of freedom } & \text { Mean Square } & \text { F-ratio } & p \text {-value } \\ \text { Model - Model } & 467,52 & 1 & 467,52 & 16621,21 & <0,0001 \\ \text { Rezidual - Residual } & 180,047 & 6401 & 0,0281279 & & \\ \text { Ukupno - Total (Corr.) } & 647,567 & 6402 & & \end{array}$

kada se radi o njegovoj praktičnoj primjeni za procjenu debljine kore kod izmjere dimenzija i preuzimanja oblog drva sa stovarišta, nije poznato iz kojeg dijela debla potječu pojedini komadi. Stoga je ovaj model trenutno neprimjenjiv u operativnom radu u šumarstvu bez izmjene pravila i propisa identifikacije i označavanja oblog drva. Zbog toga je izrađen model za procjenu dvostruke debljine kore na osnovi samo jedne nezavisne varijable - promjer dijela debla s korom (Ds sekcije), koja u šumarskoj praksi BiH, uz izmjeru duljine, služi kao osnova za utvrđivanje obujma oblog drva. Kao i u prethodno opisanom postupku nezavisna varijabla (Ds sekcije) korištena je u svojoj transformiranoj formi. Nakon provjere više jednostavnih regresijskih modela kao optimalan model odabran je sljedeći:

$$
\begin{aligned}
& D_{\text {kore }}^{0,175}=\operatorname{sqrt}\left(0,638098+0,557834 \cdot D_{\text {Ssekcije } \left.^{0,158^{2}}\right) \text { ili }}\right. \\
& D_{\text {kore }}=\left(\sqrt{0,638098+0,557834 \cdot D_{S_{\text {sekcije }}}^{0,316}}\right)^{5,7143}
\end{aligned}
$$

Za odabranu funkciju regresije koeficijent determinacije je $\mathrm{R}^{2}=0,722$. Prema tomu, izostavljanjem utjecajnog faktora
$\mathrm{DIO}_{\text {debla }}$ izgubljeno je samo oko 1,9\% objašnjenja varijabilnosti debljine kore. Utvrđene veličine statističkih pokazatelja koje su prikazane u tablicama 5 i 6 ukazuju na visoku statističku značajnost parametara modela.

Ovisnost dvostruke debljine kore bukve o srednjem promjeru sekcije po izabranoj funkciji prikazana je na slici 4 .

Za odabrani model su izračunata odstupanja stvarnih od procijenjenih veličina dvostruke debljine kore (reziduali), a na temelju njih standardna devijacija $\left(S_{d}=2,15 \mathrm{~mm}\right)$ i standardna pogreška procjene $\left(S_{e}=0,027 \mathrm{~mm}\right)$. Analiza reziduala pokazala je da nema njihovog sistematskog odstupanja ni u jednom dijelu domena funkcije (slika 5), a relativno mali broj slučajeva prelazi veličinu $\pm 3 \mathrm{~S}_{\mathrm{d}}$.

\section{Udio kore u obujmu oblog drva - Bark share in the volume of roundwood}

I udio kore u obujmu oblog drva je vrlo korisna veličina u šumarskoj praksi, jer je, između ostalog, primjena odgovarajućih tablica postotnog udjela kore jedan od standardiziranih načina redukcije obujma oblog drva s korom. U

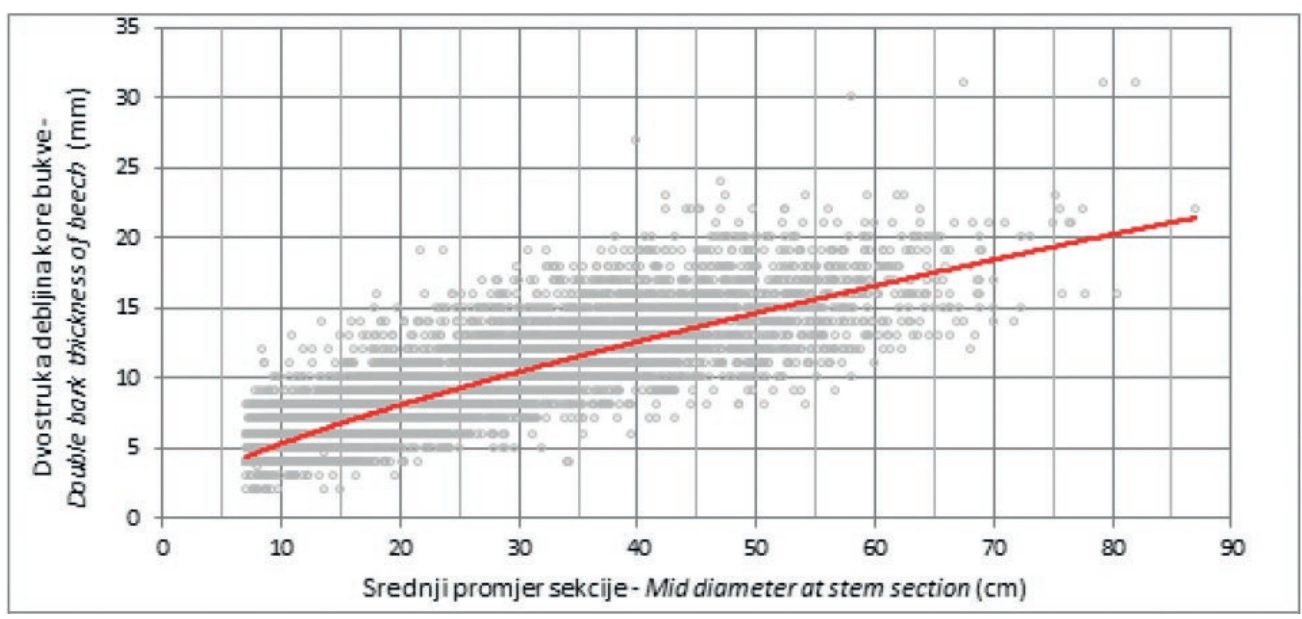

Slika 4. Dvostruka debljine kore bukve u ovisnosti o srednjem promjeru sekcije debla

Figure 4. Double bark thickness of beech depending on mid diameter at stem section 


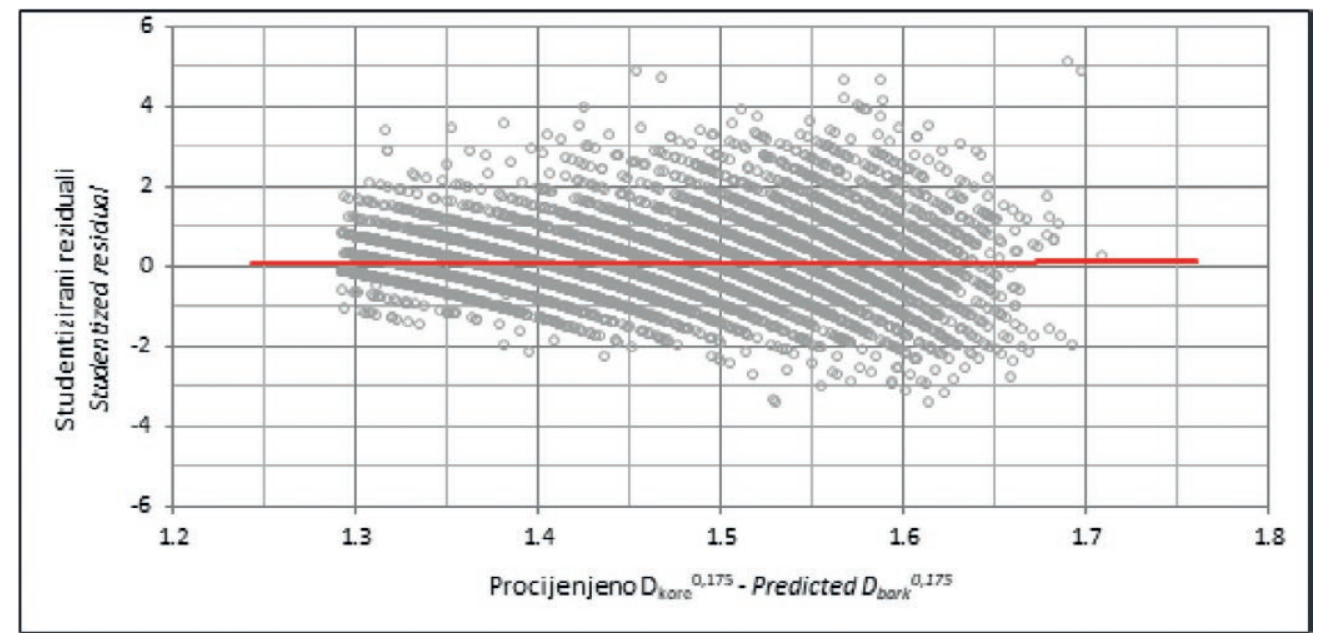

Slika 5. Odstupanja studentiziranih reziduala od modela procjene dvostruke debljine kore

Figure 5. Studentized residual deviations from the double bark thickness estimation model

vezi s ovim izvršen je obračun postotnog udjela kore bukve u obujmu sekcije (oblog drva) ovisno o promjeru po Meyerovoj formuli. Promjeri bez kore dobiveni su odbijanjem dvostruke debljine kore koja je izračunata po utvrđenom matematičkom modelu, a dobivene veličine postotnog udjela kore bukve u obujmu oblog drva, kao i dvostruka debljina kore ovisno o srednjem promjeru oblog drva prikazani su u tablici 7.

Iz podataka je vidljivo smanjivanje postotnog udjela kore s povećanjem srednjeg promjera. Ponajprije razlog za ovakvu vezu je činjenica da je prirast drva veći od prirasta kore, pa stabla većih promjera imaju postotno manji udio kore $\mathrm{u}$

Tablica 7. Dvostruka debljina i udio kore bukve u obujmu oblog drva ovisno o njegovom srednjem promjeru

Table 7. Double bark thickness and share of beech bark depending on mid diameter of roundwood

\begin{tabular}{|c|c|c|}
\hline $\begin{array}{l}\text { Srednji promjer } \\
\text { oblog drva }\end{array}$ & $\begin{array}{l}\text { Dvostruka } \\
\text { debljina kore }\end{array}$ & $\begin{array}{l}\text { Udio kore u obujmu } \\
\text { oblog drva }\end{array}$ \\
\hline $\begin{array}{l}\text { Mid diameter } \\
\text { of roundwood }\end{array}$ & $\begin{array}{l}\text { Double bark } \\
\text { thickness }\end{array}$ & $\begin{array}{l}\text { Share of bark in rouno } \\
\text { wood volume }\end{array}$ \\
\hline$(\mathrm{cm})$ & $(\mathrm{mm})$ & $(\%)$ \\
\hline 12,5 & 6,05 & 9,44 \\
\hline 17,5 & 7,42 & 8,30 \\
\hline 22,5 & 8,68 & 7,56 \\
\hline 27,5 & 9,86 & 7,04 \\
\hline 32,5 & 10,99 & 6,65 \\
\hline 37,5 & 12,08 & 6,34 \\
\hline 42,5 & 13,13 & 6,08 \\
\hline 47,5 & 14,14 & 5,87 \\
\hline 52,5 & 15,14 & 5,68 \\
\hline 57,5 & 16,11 & 5,52 \\
\hline 62,5 & 17,06 & 5,38 \\
\hline 67,5 & 17,99 & 5,26 \\
\hline 72,5 & 18,90 & 5,15 \\
\hline 77,5 & 19,81 & 5,05 \\
\hline 82,5 & 20,69 & 4,95 \\
\hline
\end{tabular}

obujmu u odnosu na tanja stabla (Prka 2004). Važno je napomenuti da su, s obzirom na način obračuna postotnog udjela kore (Meyerova formula), rezultati toliko točni koliko je točna procijenjena debljina kore.

Na osnovi rezultata prikazanih u tablici 7 može se zaključiti da su oni logični i da potvrđuju ranije ustanovljene relacije istraživanih obilježja - debljina kore bukve povećava se $s$ rastom srednjeg promjera oblog drva, dok se njen postotni udio u obujmu smanjuje. Komparirajući dobivene rezultate $s$ rezultatima drugih autora, može se zaključiti da postoje značajne razlike u debljini kore bukve između pojedinih zemalja, pa čak i između različitih regija u istoj zemlji (npr. Hrvatska), te da se ove razlike povećavaju s rastom srednjeg promjera oblog drva.

Prosječni postotni udio kore bukve u obujmu krupnog drva u ovom istraživanju iznosi 5,73\% i za 18,7\% je veće od rezultata koje je za bukvu u Hrvatskoj dobio Prka (2004) te za 9,6\% veće od rezultata Bektića (2015) za BiH. Navedene razlike ukazuju na važnost nastavka istraživanja debljine i postotnog udjela kore u obujmu tehničke oblovine i na drugim područjima u BiH kako bi se dobili pouzdaniji rezultati koji bi bili primjenjivi za cijelu državu ili parcijalno za pojedine njene dijelove, ako se razlika između područja pokaže statistički značajnom.

Dobiveni rezultati jasno ukazuju na sve manjkavosti uobičajene prakse odbijanja kore u šumarstvu F BiH. Naime, u šumarskoj praksi ne postoji nikakvo pravilo u vezi s odbijanjem kore pri izmjeri drvnih sortimenata zasnovano na odgovarajućim znanstvenim ili stručnim istraživanjima, već je to prepušteno paušalnim procjenama i/ili navodnom iskustvu uposlenika. Ovakav način izmjere drva opterećen je nedopustivo velikim pogreškama procjene, apsolutno je nepregledan i netransparentan te kao takav omogućava razne malverzacije. Posebno je ovim problemom opterećena 
izmjera i prodaja trupaca za rezanje, koji po ukupnoj vrijednosti predstavljaju najznačajniju grupu šumskih drvnih sortimenata.

\section{ZAKLJUČCI CONCLUSIONS}

$\mathrm{Na}$ osnovi rezultata istraživanja i rasprave o njima mogu se izdvojiti sljedeći bitniji zaključci:

U radu je pri modeliranju debljine kore bukve analiziran utjecaj srednjeg promjera dijela debla (oblog drva) i njegove udaljenosti od panja na debljinu kore. Provedenom GLM analizom utvrđeno je da oba navedena faktora imaju statistički značajan utjecaj na debljinu kore uz koeficijent višestruke determinacije od $\mathrm{R}^{2}=0,741$.

Debljina kore dijelova debla istog promjera raste s povećanjem njihove udaljenosti od panja prema vrhu debla, što je uvjetovano zakonitostima debljinskog prirasta.

Najveći utjecaj na debljinu kore ima izmjereni promjer oblog drva. Odabrana funkcija regresije za procjenu dvostruke debljine kore u ovisnosti o srednjem promjeru oblog drva bukve ima koeficijent determinacije $\mathrm{R}^{2}=0,722$.

$\mathrm{Na}$ osnovi odabrane funkcije jednostavne regresije izvršen je obračun dvostruke debljine kore i njenog postotnog udjela u obujmu oblog drva u ovisnosti o njegovom srednjem promjeru. Debljina kore raste s povećanjem srednjeg promjera od 6,05 mm (debljinski razred 10-15 cm) do 20,69 $\mathrm{mm}$ (debljinski razred $80-85 \mathrm{~cm}$ ). Postotni udio kore u obujmu oblog drva opada s rastom srednjeg promjera od 9,44\% (debljinski razred10-15 cm) do 4,95\% (debljinski razred $80-85 \mathrm{~cm})$.

Dobiveni rezultati predstavljaju nezaobilaznu polaznu osnovu za izradu tablica kore bukve i novog pravilnika o načinu izmjere oblog drva i utvrđivanja količina. U trenutnim odnosima šumarstva i prerade drva izrada ovog pravilnika nameće se kao nužna i prioritetna.

\section{LITERATURA}

\section{REFERENCES}

- Adler A., 2007: Accumulation of Elements in Salix and Other Species Used in Vegetation Filters with Focus on Wood Fuel Quality, Doctoral Thesis, Swedish University of Agricultural Sciences, 34 p., Uppsala.

- Althen, F.W., 1964: Accuracy of the Swedish bark measuring gauge, For. Chron., 40(2): 257-258.

- Atici, E., 2009: Bark Thickness and Ratio in Beech (Fagııs orientalis Lipsky) Forests, Journal of the Faculty of Forestry Istanbul University, 59(2): 59-84.

- Bektić, A., 2015: Debljina i zapreminsko učešće kore u drvnoj masi krupnog drveta bukve (Fagus sylvatica L.) na području GJ „Ogara-Gunjača“, Master rad, Šumarski fakultet Univerziteta u Sarajevu, 49 str., Sarajevo.
- Bonyad, A.E., A. Sima, A. Bakhshandeh, H. Dadras, 2012: Evaluation of non-destructive Meyer method for determination of bark volume of beech (Fagus orientalisLipsky) in different geographical aspects, Casp. J. of Envir. Scien., 10(1): 67-73.

- Box, G.E.P., D.R. Cox, 1964: An Analysis of Transformations, Journal of the Royal Statistical Society, Series B (Methodological), 26(2): 211-252.

- Bojanin, S. 1972: Debljina i postotak kore oblovine poljskog jasena (Fraxinus angustifolia Wahl.), Šumarski list, 7-8: 267-277.

- Božić, M., J. Čavlović, M. Vedriš, M. Jazbec, 2007: Modeliranje debljine kore stabala obične jele, Šumarski list, 1-2: 3-12.

- Cellini, J.M., M. Galarza, S.L. Burns, G.J. Martinez-Pastur, M.V. Lencinas, 2012: Equations of bark thickness and volume profiles at different heights with easy-measurement variables, Forest Systems, 21(1): 23-30.

- Doruska, P.F., D. Patterson, J. Hartley, M. Hurd, T. Hart, 2009: Newer technologies and bioenergy bring focus back to bark factor equations, J. For., 107: 38-43.

- Husch, B., T.W. Beers, J.A. Kershaw, 2003: Forest Mensuration, 4th Ed., John Wiley \& Sons, Hoboken, New Jersey, 443 p.

- Klepac, D., 1957: Istraživanja o debljini kore u šumama hrasta lužnjaka i kitnjaka, Šumarski list, 3-4: 90-106.

- Klepac, D., 1958: Funkcionalni odnos između debljine kore i prsnog promjera za naše važnije listopadno drveće, Šumarski list, 7-9: 251-267.

- Krpan, A.P.B., 1986: Kora bukve sa stanovišta eksploatacije šume, Zbornik savjetovanja „Kolokvij o bukvi“, Velika, 22.-24. 11. 1984. Šumarski fakultet Sveučilišta u Zagrebu, 77-88 str. Zagreb.

- Laasasenaho, J., T. Melkas, S. Aldén, 2005: Modelling bark thickness of Picea abies with taper curves, For. Ecol. Manage., 206:3547.

- Lojo, A., J. Musić, B. Balić, A. Avdagić, V. Halilović, A. Ibrahimspahić, J. Knežević, 2019: Debljina i udio kore u zapremini oblog drveta jele (Abies alba Mill.), Naše šume, 5455: 5-18

- Marshall, H., G.E. Murphy, K. Boston, 2006: Evaluation of the economic impacts of length and diameter measurement error on menchanical processors and harvesters operating in pine stands. Can. J. For. Res., 36: 1661-1673.

- Matić, V., 1980: Prirast i prinos šuma, Šumarski fakultet Univerziteta u Sarajevu, 351 str. Sarajevo.

- Meyer, H., 1946: Bark volume determination in trees, J. For., 44(12):1067-1070.

- Milojković, D. 1953: Istraživanje oblika i zapremine belog jasena (Fraxinus excelsior) u Ravnom Sremu, Glasnik Šumarskog fakulteta u Beogradu, 6: 127-194.

- Mesavage, C., 1969: Measuring bark thickness, J. For., 67(10): 753-754.

- Monserud R.A., 1979: Relations between inside and outside bark diameter at breast height for Douglas-fir in Northern Idaho, USDA Forest Service Research Note INT-266.

- Musić, J., A. Lojo, B. Balić, A. Ibrahimspahić, A. Avdagić, J. Knežević, V. Halilović, 2019: Modelling Bark Thickness of Norway Spruce (Picea abiesKarst), South-East Eur. For., 10(2): 125135.

- Paule, L., 1995: Gene conservation in European Beech (Fagus sylvatica L.), Forest Genetics, 2(3):161-170. 
- Poršinsky, T., J. Vujeva, 2007: Gubici obujma izrađene smrekove oblovine zbog propisanoga načina izmjere, Nova meh. šumarstva, 28(1): 37-47.

- Prka, M., 2004: Debljina kore obične bukve (Fagus sylvatica L.) u sječinama Bjelovarske Bilogore, Šumarski list, 7-8: 391-403.

- Stängle, S.M., U.H. Sauter, C.F. Dormann, 2017: Comparison of models for estimating bark thickness of Picea abies in southwest Germany: the role of tree, stand, and environmental factors, Ann. For. Sci., 74:16.

- Stängle, S.M., A.R. Weiskittel, C.F. Dormann, F. Brüchert, 2016: Measurement and prediction of bark thickness in Picea abies: assessment of accuracy, precision, and sample size requirements, Can. J. For. Res., 46(1): 39-47.
- Stankić, I., S. Kovač, T. Poršinsky, 2010: Značajke kore podravske crne johe, Nova mehanizacija šumarstva, 31(1): 27-36.

- Stefanović, V., V. Beus, Č. Burlica, H. Dizdarević, I. Vukorep, 1983: Ekološko-vegetacijska rejonizacija Bosne i Hercegovine, Šumarski fakultet u Sarajevu, posebna izdanja 17, 51 str., Sarajevo.

- Trinajstić, I., 2003: Taksonomija, morfologija i rasprostranjenost obične bukve. In: Matić S. (ed), Obična bukva u Hrvatskoj, Akademija šumarskih znanosti, 33-56 str., Zagreb.

- Wilhelmsson, L., J. Arlinger, K. Spångberg, S.-O. Lundqvist, T. Grahn, O. Hadenberg, L. Olsson, 2002: Models for Predicting Wood Properties in Stems of Picea abies and Pinus sylvestris in Sweden, Scand. J. For. Res., 17: 330-350.

\section{SUMMARY}

Thickness and share in volume of tree and/or round wood represent the most important features of the bark, especially in the process of timber harvesting, during scaling of processed logs. In forestry of Federation of B\&H there are no rules or tables for deduction of double bark thickness based on scientific research. Wood assortments tables for our most important tree species, besides a whole series of wood assortments, also contain the category of waste. From a practical point of view this category can be divided into "real waste" and losses. The real waste in this sense consists of various logging slash and sawdust, while the loss constitutes a prescribed method of measuring the dimensions and calculation of volume and the deduction of the double bark thickness. So, it is very important to have relatively accurate data of the bark thickness for certain tree species. Therefore, the objecti ve of this paper is to explore double bark thickness and share of bark in the volume of beech round wood. The research was carried out in the area of the Canton 10 of Federation of B\&H. The research included 678 sample trees from $10 \mathrm{~cm}$ to $85 \mathrm{~cm}$ diameter breast height (DBH) and from $5 \mathrm{~m}$ to $40 \mathrm{~m}$ of height with 6,403 pairs were measured for double bark thickness and diameter in the middle of the round wood (section). Data of double bark thickness in relation to mid diameter of round wood were equalized by following equation with coefficient of determination $\mathrm{R}^{2}=0.722$.

The results of research confirmed the regularities defined in previous research and has shown as follows: a) by the increase of mid diameter of round wood, double bark thickness increases from 6.05 $\mathrm{mm}$ (thickness class $12.5 \mathrm{~cm}$ ) to $20.69 \mathrm{~mm}$ (thickness class $82.5 \mathrm{~cm}$ ), b) by the increase of mid diameter of round wood, bark share in the volume decrease exponentially from $9.44 \%$ (thickness class 12.5 $\mathrm{cm}$ ) to $4.95 \%$ (thickness class $82.5 \mathrm{~cm}$ ). The research have indicated the need to use the results and incorporating it into applicable rules of deducting the bark on logs or share of bark in the volume depending on diameter over the bark.

KEY WORDS: beech, bark thickness, bark share, round wood 